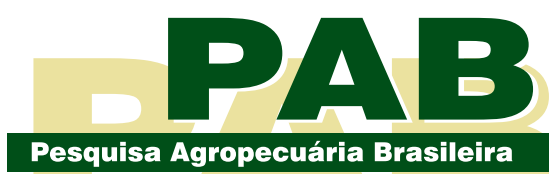

ISSN 1678-3921

Journal homepage: www.embrapa.br/pab

For manuscript submission and journal contents, access: www.scielo.br/pab

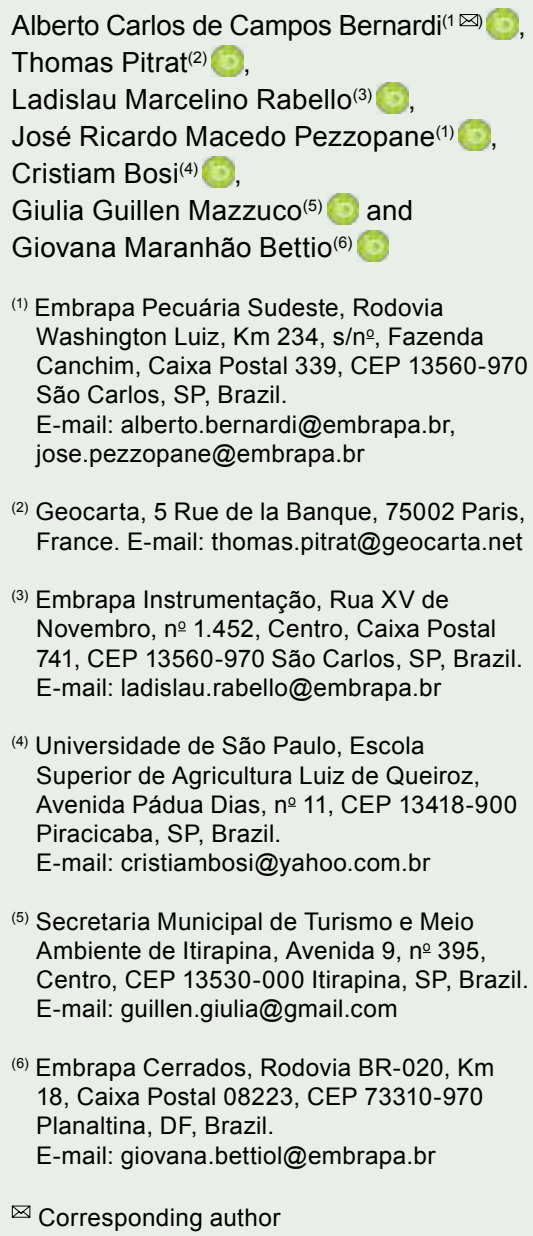

(2) Geocarta, 5 Rue de la Banque, 75002 Paris, France. E-mail: thomas.pitrat@geocarta.net

(3) Embrapa Instrumentação, Rua XV de Novembro, no 1.452, Centro, Caixa Postal 741, CEP 13560-970 São Carlos, SP, Brazil. E-mail: ladislau.rabello@embrapa.br

(4) Universidade de São Paulo, Escola Superior de Agricultura Luiz de Queiroz, Avenida Pádua Dias, № 11, CEP 13418-900 Piracicaba, SP, Brazil.

E-mail: cristiambosi@yahoo.com.br

(5) Secretaria Municipal de Turismo e Meio Ambiente de Itirapina, Avenida 9, oㅡ 395, Centro, CEP 13530-000 Itirapina, SP, Brazil. E-mail: guillen.giulia@gmail.com

(6) Embrapa Cerrados, Rodovia BR-020, Km 18, Caixa Postal 08223, CEP 73310-970 Planaltina, DF, Brazil. E-mail: giovana.bettiol@embrapa.br

$\bowtie$ Corresponding author

Received

May 5, 2018

Accepted

October 25, 2019

How to cite

BERNARDI, A.C. de C.; PITRAT, T.; RABELLO, L.M.; PEZZOPANE, J.R.M.; BOSI, C.; MAZZUCO, G.G.; BETTIOL, G.M. Differences in soil electrical resistivity tomography due to soil water contents in an integrated agricultural system. Pesquisa Agropecuária Brasileira, v.54, e00774, 2019. DOI: https://doi.org/10.1590/S1678-3921. pab2019.v54.00774

\section{Differences in soil electrical resistivity tomography due to soil water contents in an integrated agricultural system}

\begin{abstract}
The objective of this work was to characterize the spatial variability of soil electrical resistivity due to different soil moisture contents, in an integrated agricultural system. Soil electrical resistivity (ER) was measured with the Automatic Resistivity Profiling (ARP) contact sensor in two dates, in 2016, in a 9.7-ha area with different soil moisture contents. The obtained maps indicated that ER allowed delimiting the regions within the study area and pointing out differences in the movement and accumulation of water in the soil horizons. Although there is a trend of reduction in ER values with increasing soil moisture, the spatial correlation structure of ER is similar.
\end{abstract}

Index terms: ARP system, soil sensor, soil water content.

\section{Diferenças na tomografia da resistividade elétrica do solo devido aos níveis de água em sistema agropecuário integrado}

Resumo - O objetivo deste trabalho foi caracterizar a variabilidade espacial da resistividade elétrica do solo devido a diferentes umidades do solo, em sistema agropecuário integrado. A resistividade elétrica (RE) do solo foi medida com o sensor de contato "Automatic Resistivity Profiling" (ARP) em duas datas, em 2016, em área de 9,7 ha com diferentes umidades do solo. Os mapas obtidos indicaram que a RE permitiu delimitar as regiões dentro da área de estudo e indicar diferenças do movimento e da acumulação de água nos horizontes do solo. Apesar da tendência de redução dos valores da RE com o aumento da umidade do solo, a estrutura de correlação espacial da RE é similar.

Termos para indexação: sistema ARP, sensor de solo, teor de água no solo.

Electrical resistivity (ER) tomography is a noninvasive method used to measure the distribution of electrical conductivity (EC) within the soil subsurface using electrodes (Michot et al., 2003; Samouëlian et al., 2005; Vereecken et al., 2014). ER is a function of soil structure and texture and is also affected by water content and salinity (Zhou et al., 2001; Samouëlian et al., 2005; Besson et al., 2010; Andrenelli et al., 2013). Although soils are porous media composed of nonconductive solid particles (Michot et al., 2003), they contain pores that may allow the conduction of an electric current due to the movement of free ions in the soil solution or to water adsorbtion by the surface of the matrix (Samouëlian et al., 2005). Because of its sensitivity to soil properties, 
ER is adequate for mapping and evaluating the properties of agricultural land, soil nutrient cycling and storage, and soil hydrological processes, as well as for characterizing field variability in precision agriculture (Loke et al., 2013).

Regarding precision agriculture management, knowledge about the spatial variation of soil properties within fields is important. Proximal soil sensors to measure soil ER or EC are useful tools for the on-thego assessment of soil spatial and temporal variability (Besson et al., 2010; Serrano et al., 2013; Andrenelli et al., 2013; Pedrera-Parrilla et al., 2016).

It should be noted that the use of direct-current resistivity to characterize properties of agricultural soils is a new challenge and an active research area (Besson et al., 2010). In field studies, ER was used to monitor water dynamics in the soil in experiments under controlled conditions (Vereecken et al., 2014); the advantage is that changes caused by ER can be easily attributed to differences in soil moisture or to the ER of the soil solution. However, few studies have been conducted to monitor changes in ER as a function of soil moisture in a field scale (Michot et al., 2003; Besson et al., 2010). ER and its reciprocal, $\mathrm{EC}$, have played an essential role in agriculture and soil science for many years, since they are among the most useful and easily obtained soil spatial properties that influence crop productivity (Loke et al., 2013). ER and EC have also been successfully applied to define management zones on farms (Samouëlian et al., 2005; Loke et al., 2013; Fortes et al., 2015).

The objective of this work was to characterize the spatial variability of soil ER due to different soil moisture contents, in an integrated agricultural system.

The study was conducted in a 9.7-ha area at Embrapa Pecuária Sudeste, in the municipality of São Carlos, in the state of São Paulo, Brazil (2158'20''S, 4751'10'”W, $860 \mathrm{~m}$ above sea level). The soil is classified as a Latossolo Vermelho-Amarelo distrófico (Santos et al., 2013), i.e., a Haplortox. Soil texture is sandy clay (Calderano Filho et al., 1998), with: $760 \mathrm{~g} \mathrm{~kg}^{-1}$ sand, $19 \mathrm{~g} \mathrm{~kg}^{-1}$ silt, and $221 \mathrm{~g} \mathrm{~kg}^{-1}$ clay at $0.0-0.2-\mathrm{m}$ depth; and $706 \mathrm{~g} \mathrm{~kg}^{-1}$ sand, $16 \mathrm{~g} \mathrm{~kg}^{-1}$ silt, and $278 \mathrm{~g} \mathrm{~kg}^{-1}$ clay at $0.80-1.00-\mathrm{m}$ depth. The climate is classified as Cwa according to Köppen-Geiger, with two well-defined seasons: dry, from April to September, with an average temperature and precipitation of $19.9^{\circ} \mathrm{C}$ and $250 \mathrm{~mm}$, respectively; and rainy, from October to March, with an average temperature and precipitation of $23.0^{\circ} \mathrm{C}$ and $1,100 \mathrm{~mm}$, respectively (Rolim et al., 2007). The integrated agricultural system, described by Pezzopane et al. (2019), includes different combinations of Urochloa brizantha 'Piatã' grass, partially renovated every three years, intercropped with corn (Zea mays L.), planted together with Eucalyptus urograndis trees (15x2-m spacing).

ER was measured on two dates: 5/4/2016 and 6/1/2016, using the Automatic Resistivity Profiling (ARP) system (Geocarta, Paris, France). The sensor used to measure ER had eight electrodes on discs with tips in the outskirt format: two are transmitters and six are current recipients. Soil ER data $(\Omega \mathrm{m})$ was obtained at three depths: $0.0-0.5,0.0-1.0$, and $0.0-2.0 \mathrm{~m}$, being collected every $0.1 \mathrm{~m}$ (distance controlled by radar). The geographical coordinates of each measurement point were recorded with the GPSMAP 60CSx (Garmin International, Inc., Olathe, KS, USA). The distance between passes was approximately $6 \mathrm{~m}$.

Soil moisture content up to $1.0-\mathrm{m}$ depth was continuously monitored with the Diviner 2000 probe (Sentek, Stepney, Australia). Weather data (temperature and rainfall) were collected, and water balance was calculated from July 2015 to June 2016 (Figure 1).

Data interpolation was carried out by the inverse distance weighting method, and contour maps were generated using the ArcGIS 10.1 software (ESRI, Redlands, CA, USA). From the shapefiles, a virtual sampling grid of 500 points was adopted for the correlation study.

Between the ER measurement dates, a 216-mm rainfall was recorded in the studied area, indicating the accumulation of water in the soil (Figure 1). In both dates, the recorded soil moisture contents up to 1.0$\mathrm{m}$ depth were, respectively, 0.208 and $0.283 \mathrm{~cm}^{3} \mathrm{~cm}^{-3}$. Changes in ER due to rainfall and seasonal variations in temperature and soil water contents were also reported by Zhou et al. (2001), Serrano et al. (2013), and Pedrera-Parrilla et al. (2016).

The obtained results confirm that the ER ground sensor is a noninvasive tool that can be a quick and low-cost alternative for the physical characterization of soils with a high level of spatial details. The equipment collects points by standard distance intervals of $0.1 \mathrm{~m}$ and has a significant advantage for use in the field: speed variation does not affect the density of the 
sampled points. Therefore, the collected data set is vast, as observed in the present study, with approximately 81,000 and 55,000 sampling points, respectively, in the first and second measurements, for the 9.7-ha area.

After the interpolation of the ER data for all three depths, four classes were established (Figure 2). The class values were automatically divided by the equal interval classification method into equal-sized subintervals, using the ArcGIS 10.1 software (ESRI, Redlands, CA, USA). The results indicated that ER decreased as water content increased, as pointed out by Samouëlian et al. (2005). Although lower ER values were obtained during the wet period compared with the drier one, a similar spatial correlation structure was observed, which can indicate a temporally stable ER pattern.
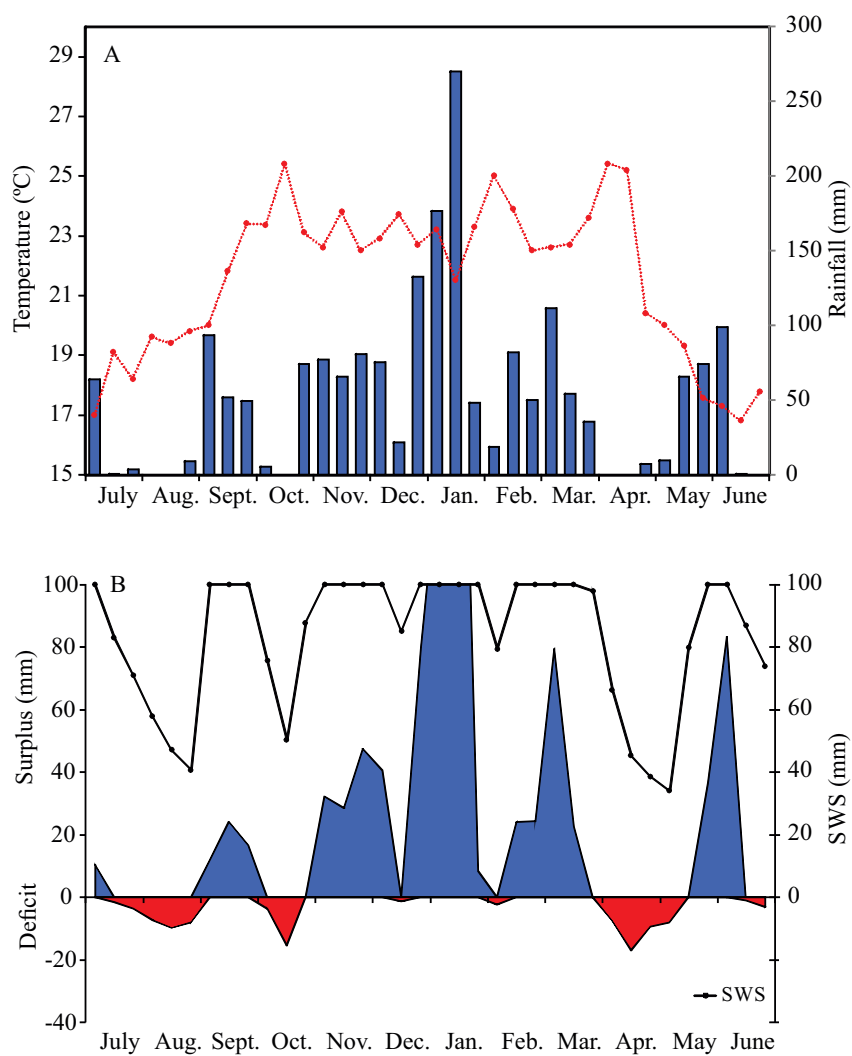

Figure 1. Temperature and rainfall data (A) and water balance (B) from July 2015 to June 2016 in the municipality of São Carlos, in the state of São Paulo, Brazil. SWS, soil water storage.
Figure 2 shows the soil moisture content map under dry $\left(0.208 \mathrm{~cm}^{3} \mathrm{~cm}^{-3}\right)$ and wet $\left(0.283 \mathrm{~cm}^{3} \mathrm{~cm}^{-3}\right)$ soil conditions in the study field. Serrano et al. (2013) obtained results similar to those of the present study, in which a significant linear correlation was verified between ER values collected in May (dry) and June (wet), with correlation coefficients of $r=0.55$ at 0.0 $0.5-\mathrm{m}$ depth and $\mathrm{r}=0.65$ at $0.0-1.0$ and $0.0-2.0-\mathrm{m}$ depths. ER values were higher in May than in June, which confirms the influence of soil moisture content on soil ER (Samouëlian et al., 2005; Besson et al., 2010). These results show the temporal stability of the ER patterns at different soil moisture contents. These correlation values are indicative that the adopted tool can be used for studies of temporal variability, as also concluded by Serrano et al. (2013) and Pedrera-Parrilla et al. (2016).

The measurements at the $0.0-0.5$ and $0.0-1.0-$ $\mathrm{m}$ depths indicated little variation between both sampling dates (Figure 2). Additionally, the observed trends were the same, with an increase in the area of class 1 , from 4 to $12 \%$ of the total area. At both depths, most of the ER measurements were in classes 2 and 3, which represented 40 to $50 \%$ of the total area. The most substantial variations were verified in the measurements at a depth of $0.0-2.0 \mathrm{~m}$, initially mainly in classes 2 and 3, representing 48 and $43 \%$ of the area, respectively; with the accumulation of water after rainfall, the measured values changed predominantly to classes 1 and 2, representing 36 and $62 \%$ of the area. The similar variations observed for the different zones indicate the high rates of water infiltration in the studied Latossolo Vermelho-Amarelo, and that the water flows were mainly vertical in the field, as already pointed out by Besson et al. (2010). The stable temporal pattern of soil conductivity as a function of soil water content was also shown by Serrano et al. (2013) and Pedrera-Parrilla et al. (2016).

The obtained results are indicative that the addition of resistivity data in two different dates with varying soil moisture contents, as well as the adopted interpretation procedure, could be used to determine the temporal variation of moisture content in the soil profile. Of course, further measurements in other humidity conditions may further reinforce these observations.

Although ER may vary due to different soil properties, such as porosity, structure, temperature, 
and chemical composition of the solution (Samouëlian et al., 2005; Vereecken et al., 2014), the results of the present study show that ER values also changed over time due to weather and soil conditions (Figure 1), but following a same trend. According to Zhou et al. (2001), ER measurements allow predicting the volumetric
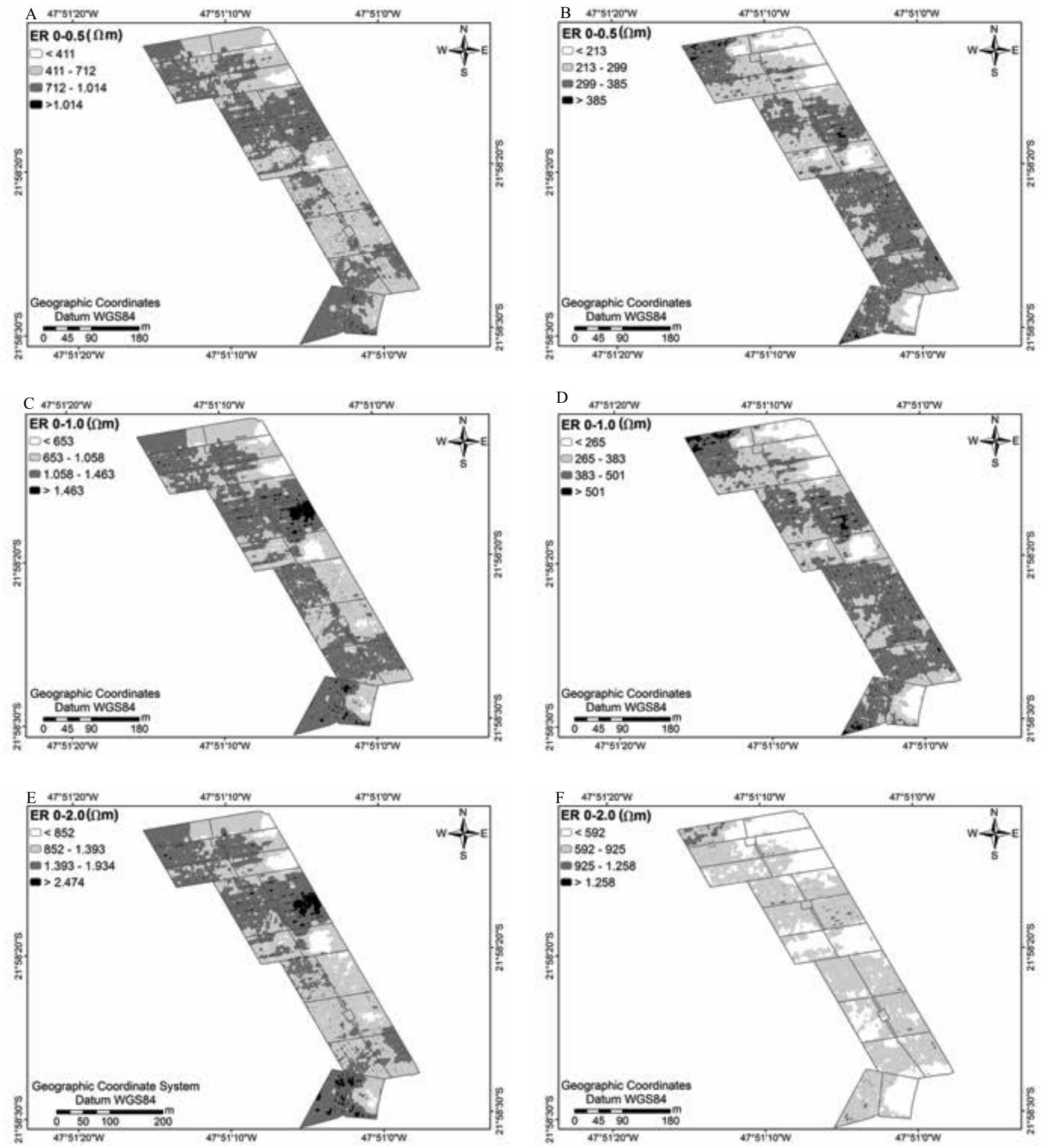

Figure 2. Interpolated maps of soil electrical resistivity (ER) at the $0.0-0.5,0.0-1.0$, and $0.0-2.0-\mathrm{m}$ depths, with soil moisture content of 0.208 and $0.283 \mathrm{~cm}^{3} \mathrm{~cm}^{-3}$, respectively, on May 4 and June 1, 2016. 
water content. The results obtained in the present work confirm the possible use of ER measurements as a supplemental tool for studies in soil science and agronomy, to indicate the spatial variability of soil properties.

Electrical resistivity tomography allowed delimiting the regions within the study area and indicating differences in the movement and accumulation of water in the soil horizons, as already shown by Samouëlian et al. (2005), Loke et al. (2013), and Fortes et al. (2015). Although there is a trend of reduction in ER values with increasing soil moisture, the spatial correlation structure of ER is similar.

\section{Acknowledgments}

To Geocarta, for area mapping; and to Associação Rede ILPF, for financial support.

\section{References}

ANDRENELLI, M.C.; MAGINI, S.; PELLEGRINI, S.; PERRIA, R.; VIGNOZZI, N.; COSTANTINI, E.A.C. The use of the ARP( system to reduce the costs of soil survey for precision viticulture. Journal of Applied Geophysics, v.99, p.24-34, 2013. DOI: https:// doi.org/10.1016/j.jappgeo.2013.09.012.

BESSON, A.; COUSIN, I.; BOURENNANE, H.; NICOULLAUD, B.; PASQUIER, C.; RICHARD, G.; DORIGNY, A.; KING, D. The spatial and temporal organization of soil water at the field scale as described by electrical resistivity measurements. European Journal of Soil Science, v.61, p.120-132, 2010. DOI: https://doi. org/10.1111/j.1365-2389.2009.01211.x.

CALDERANO FILHO, B.; SANTOS, H.G. dos; FONSECA, O.O.M. da; SANTOS, R.D. dos; PRIMAVESI, O.; PRIMAVESI, A.C. Os solos da fazenda Canchim, Centro de Pesquisa de Pecuária do Sudeste, São Carlos, SP: levantamento semidetalhado, propriedades e potenciais. Rio de Janeiro: EMBRAPA-CNPS; São Carlos: EMBRAPA -CPPSE, 1998. 95p. (EMBRAPA-CNPS. Boletim de pesquisa, 7; EMBRAPA-CPPSE. Boletim de pesquisa, 2).

FORTES, R.; MILlÁN, S.; PRIETO, M.H.; CAMPILlO, C. A methodology based on apparent electrical conductivity and guided soil samples to improve irrigation zoning. Precision Agriculture, v.16, p.441-454, 2015. DOI: https://doi.org/10.1007/ s11119-015-9388-7.

LOKE, M.H.; CHAMBERS, J.E.; RUCKER, D.F.; KURAS, O.; WILKINSON, P.B. Recent developments in the directcurrent geoelectrical imaging method. Journal of Applied
Geophysics, v.95, p.135-156, 2013. DOI: https://doi.org/10.1016/j. jappgeo.2013.02.017.

MICHOT, D.; BENDERITTER, Y.; DORIGNY, A.; NICOULlAUD, B.; KING, D.; TABBAGH, A. Spatial and temporal monitoring of soil water content with an irrigated corn crop cover using surface electrical resistivity tomography. Water Resources Research, v.39, art.1138, 2003. DOI: https://doi. org/10.1029/2002WR001581.

PEDRERA-PARRILLA, A.; VAN DE VIJVER, E.; VAN MEIRVENNE, M.; ESPEJO-PÉREZ, A.J.; GIRÁLDEZ, J.V.; VANDERLINDEN, K. Apparent electrical conductivity measurements in an olive orchard under wet and dry soil conditions: significance for clay and soil water content mapping. Precision Agriculture, v.17, p.531-545, 2016. DOI: https://doi. org/10.1007/s11119-016-9435-z.

PEZZOPANE, J.R.M.; BERNARDI, A.C.C.; BOSI, C.; OLIVEIRA, P.P.A.; MARCONATO, M.H.; PEDROSO, A. de F.; ESTEVES, S.N. Forage productivity and nutritive value during pasture renovation in integrated systems. Agroforestry Systems, v.93, p.39-49, 2019. DOI: https://doi.org/10.1007/ s10457-017-0149-7.

ROLIM, G. de D.S.; CAMARGO, M.B.P. de; LANIA, D.G.; MORAES, J.F.L. de. Classificação climática de Köppen e de Thornthwaite e sua aplicabilidade na determinação de zonas agroclimáticas para o estado de São Paulo. Bragantia, v.66, p.711-720, 2007. DOI: https://doi.org/10.1590/S000687052007000400022 .

SAMOUËLIAN, A.; COUSIN, I.; TABBAGH, A.; BRUAND, A.; RICHARD, G. Electrical resistivity survey in soil science: a review. Soil and Tillage Research, v.83, p.173-193, 2005. DOI: https://doi.org/10.1016/j.still.2004.10.004.

SANTOS, H.G. dos; JACOMINE, P.K.T.; ANJOS, L.H.C. dos; OLIVEIRA, V.A. de; LUMBRERAS, J.F.; COELHO, M.R.; ALMEIDA, J.A. de; CUNHA, T.J.F.; OLIVEIRA, J.B. Sistema brasileiro de classificação de solos. 3.ed. rev. e ampl. Brasília: Embrapa, 2013. 353p.

SERRANO, J.M.; SHAHIDIAN, S.; SILVA, J.R.M. da. Apparent electrical conductivity in dry versus wet soil conditions in a shallow soil. Precision Agriculture, v.14, p.99-114, 2013. DOI: https://doi.org/10.1007/s11119-012-9281-6.

VEREECKEN, H.; HUISMAN, J.A.; PACHEPSKY, Y.; MONTZKA, C.; VAN DER KRUK, J.; BOGENA, H.; WEIHERMÜLLER, L.; HERBST, M.; MARTINEZ, G.; VANDERBORGHT, J. On the spatio-temporal dynamics of soil moisture at the field scale. Journal of Hydrology, v.516, p.76-96, 2014. DOI: https://doi.org/10.1016/j.jhydrol.2013.11.061.

ZHOU, Q.Y.; SHIMADA, J.; SATO, A. Three-dimensional spatial and temporal monitoring of soil water content using electrical resistivity tomography. Water Resources Research, v.37, p.273285, 2001. DOI: https://doi.org/10.1029/2000WR900284. 